\title{
Penyusunan Basis Data Spasial Fasilitas Bangunan Gedung bagi Penyandang Disabilitas (Universitas Gadjah Mada Menuju Kampus Inklusi)
}

\author{
R. Suharyadi ${ }^{{ }^{*}}$, Iswari Nur Hidayati ${ }^{1}$ dan Wuri Handayani ${ }^{2}$ \\ Departemen Sains Informasi Geografi, Fakultas Geografi, Universitas Gadjah Mada, Yogyakarta, Indonesia. \\ Departemen Akuntansi, Fakultas Ekonomika dan Bisnis, Universitas Gadjah Mada²
}

*Email koresponden: suharyadir@ugm.ac.id

Direvisi: 2019-12-03. Diterima: 2020-04-21

(C2020 Fakultas Geografi UGM dan Ikatan Geograf Indonesia (IGI)

\begin{abstract}
Abstrak Sebagai universitas terkemuka di Indonesia, Universitas Gadjah Mada (UGM) telah berkomitmen menjadi kampus inklusi. Konsekuensi dari komitmen menjadi kampus inklusi mengharuskan penyelenggara pendidikan tinggi untuk menyediakan fasilitas sesuai dengan kebutuhan penyandang disabilitas. Untuk menyediakan fasilitas yang memadai, maka penyusunan basis data spasial bangunan gedung dengan informasi fasilitas penyandang disabilitas perlu diwujudkan. Tujuannya, untuk mengidentifikasi sarana dan prasarana yang saat ini sudah ada, sekaligus memberikan masukan untuk peningkatan fasilitas yang dapat diakses dengan prinsip kemudahan, keamanan dan kenyamanan bagi penyandang disabilitas. Dengan demikian, tujuan penelitian ini adalah (1) menginventarisasi dan menyusun basis data spasial bangunan gedung bagi penyandang disabilitas di lingkungan kampus UGM, (2) memberi rekomendasi penyediaan bangunan fasilitas yang dapat diakses bagi penyandang disabilitas di lingkungan kampus UGM. Interpretasi visual citra penginderaan jauh digunakan sebagai teknik ekstraksi bangunan Gedung di lingkungan Kampus UGM. Survei lapangan dilakukan dengan cara sensus pada seluruh bangunan gedung di lingkungan kampus UGM untuk mendapatkan data jenis fasilitas bangunan bagi penyandang disabilitas. Penyusunan basis data spasial menggunakan fasilitas sistem informasi geografi. Hasil penelitian berupa basis data spasial fasilitas bangunan gedung bagi penyandang disabilitas di lingkungan kampus UGM. Atribut yang menyertai dalam basis data fasilitas bangunan bagi penyandang disabilitas, berupa : ramp atau lift, guiding block, dan fasilitas toilet.
\end{abstract}

Kata kunci: basis data; ramah disabilitas; kampus inklusi

Abstract As one of prominent university in Indonesia, Universitas Gadjah Mada (UGM) committed to be an inclusive campus. This means that the campus is friendly to people with disabilities. As a consequence, providing the accessible facilitas for disabled students is a crucial. In order to support in providing the facilities, spatial database compilation of buildings with information on facilities for persons with disabilities needs is required. The compiled database derived from remote sensing imagery, and utilize geographic information system for spatial data collecting. Hence, the research objective is (1) to iventory and compile a database of buildings and facilities for disabled people in UGM through utilizing remote sensing images as the data source and (2) providing recommendation for the provisions of accessible facilities for disabled people in UGM. Therefore, visual interpretation is the method for gathering the building information in UGM. The remote sensing image utilized is a small formal aerial photograph that is photograph using unmanned aircraft. Field surveys were carried out in a censes on all buildings on the UGM. The way to compile the spatial database will use the GIS techniques. The study result were spatial data building and facilities for disabilities that equipped with accessibility for disabled people such as ramps or elevators, guiding blocks, and toilet facilities.

Keywords: database; disabilities; inclusion campus

\section{PENDAHULUAN}

Universitas Gadjah Mada (UGM) merupakan salah satu universitas negeri di Indonesia yang mempunyai komitmen tinggi memberikan akses pendidikan bagi seluruh warga negara. Komitmen tersebut dibuktikan dengan memberikan program afirmasi untuk masuk ke UGM bagi warga negara dari daerah tertinggal, terdepan, terluar (3T), juga kepada penyandang disabilitas melalui pendidikan inklusif. Filosofi pendidikan inklusif adalah memberikan hak pendidikan yang sama kepada anak didik dari berbagai latar belakang fisik, ekonomi, budaya dan karakteristik lainnya untuk bersama sama berpartisipasi aktif dan mengembangkan potensi mere ka dalam proses belajar (Morina, 2017). Dengan demikian, nilai-nilai dari pendidikan inklusif adalah partisipasi, demo krasi, keadilan dan akses yang sama (Haug, 2017). Berbagai penelitian telah mengidentifikasi manfaat pendidikan inklusif, yaitu mendorong interaksi, komunikasi dan kolaborasi, baik antar anak didik maupun dengan tenaga pengajar (Tuggar, 2014). Melalui pendidikan inklusi juga, tujuan akhir pendidikan yaitu toleransi akan dapat dicapai (Čerešňová, 2018).
Namun, implementasi pendidikan inklusif, terutama bagi penyandang disabilitas memiliki tantangan tersendiri karena mengharuskan institusi pendidikan melakukan penyesuaian yang memadai (reasonable adjustment) untuk menghilangkan hambatan (barriers) dan diskrimininasi, tanpa mengabaikan kualitas pendidikan (Mag et al., 2017). Selanjutnya, penelitian yang dilakukan di berbagai negara dalam mengidentifikasi hambatan dalam implementasi pendidikan inklusif menyimpulkan bahwa tantangan terbesar dalam implementasi pendidikan inklusif adalah hambatan arsitektur/bangunan (architectural barriers), diikuti dengan akses terhadap kurikulum, sistem evaluasi dan juga penilaian (Hewett et al., 2018; Morgado et al., 2016). Dalam kaitannya mengurangi hambatan arsitektur yang juga dialami maha siswa penyandang disabilitas, Rencana Strategis (Renstra) UGM 2017-2022 dalam bidang infrastruktur dan lingkungan telah mencantumkan penyediaan peralatan akses gedung dan fasilitas bagi disabilitas civitas akademika. Dalam kaitannya dengan menghilangkan hambatan arsitektur sekaligus meningkatkan penyediaan fasilitas yang dapat diakses di 
Lingkungan Kampus UGM, maka perlu dilakukan inventor isasi fasilitas yang ada (existing facilities), melakukan evaluasi ketersediaan fasilitas dan merekomendasikan kebutuhan mengajukan rekomendasi penambahan fasilitas yang memadai bagi penyandang disabilitas (Moriña Díez et al., 2015). Untuk itulah penelitian ini bertujuan melakukan inventor isasi dan menyusun basis data spasial fasilitas di bangunan gedung dan lingkungan yang dapat diakses, yakni fasilitas yang dapat diakses dan digunakan oleh semua orang secara mudah, aman, nyaman dan mandiri secara berkeadilan sesuai dengan amanah Peraturan Menteri Pekerjaan Umum dan Perumahan Rakyat RI No. 14/PRT/ $\mathrm{M} / 2017$ tentang persyara tan kemudahan bangunan gedung.

Untuk membantu menyusun basis data spasial fasilitas bangunan gedung bagi penyandang disabilitas, maka diperlukan teknologi yang tepat guna. Salah satu teknologi yang sesuai sebagai sumber data spasial adalah citra penginderaan jauh. Citra penginderaan jauh banyak digunakan sebagai sumber data spasial survei daerah perkotaan dipicu oleh keberadaan citra satelit resolusi spasial baik. Sejak pe luncuran satelit sumberdaya bumi Landsat-1 tahun 1970-an, jumlah penelitian dengan objek daerah perkotaan meningkat dengan tajam (Herold et al., 2003; Suharyadi, 2011). Pada saat itu penginderaan jauh untuk studi daerah perkotaan sedang mencari jati diri yaitu ditandai dengan banyaknya penelitian yang bersifat eksperimental pada bidang survei daerah perkotaan (Suharyadi, 2014; Yang \& Liu, 2005). Hasil kajian citra penginderaan jauh belum dapat memasuki ranah operasional secara penuh, para pengelola daerah perkotaan masih meragukan kualitas data spasial yang diperoleh dari interpretasi citra penginderaan jauh. Paradigma yang digunakan oleh para pengelola daerah perkotaan saat itu ada lah, pengelola daerah perkotaan memerlukan data spasial terbaru yang dapat berpacu dengan perkembangan, maka data spasial yang diperlukan harus memenuhi kualifikasi: rinci, validitas baik, dan muthakir.

Gulko, V.V. dan Zatserkovnyi, V.I. (2018) membuat ke simpulan tentang pemanfaatan citra penginderaan jauh dalam bidang perkotaan, yaitu citra penginderaan jauh telah menjadi data dasar geospasial yang kongkrit sebagai sumber data yang handal untuk membangun beberapa terapan seperti manajemen sumberdaya alam, pengelolaan wilayah, invent tarisasi dan pemutakhiran data topografi. Penelitian ini mengkaji kenberadaan asilitas bangunan gedung bagi penyandang disabilitas di lingkungan kampus UGM dengan memanfaakan citra penginderaan jauh, menyusun basis data spasial fasilitas bangunan gedung bagi penyandang disabilitas, dan rekomendasi pengembangan fasilitas bangunan gedung bagi penyandang disabilitas.

\section{METODE PENELITIAN}

Penelitian dilakukan di lingkungan kampus UGM, Bulak Sumur, Yogyakarta. Kampus UGM menempati lahan seluas hampir $3.000 .000 \mathrm{~m}^{2}$, di atasnya berdiri 670 buah gedung dengan luas total $740.000 \mathrm{~m}^{2}$, dan luas ruang terbuka hijau sekitar $692.800 \mathrm{~m}^{2}$ Data yang digunakan dalam penelitian ini meliputi data spasial dan data tabuler. Data spasial berupa bangunan gedung bersumber dari interpretasi citra penginderaan jauh, sedangkan data tabuler berupa informasi pemanfaatan gedung dan keberadaan fasilitas bagi penyan dang disabilitas bersumber dari survei lapangan. Secara rinci jenis data dan sumber data dapat dilihat pada tabel 1 .

Citra penginderaan jauh yang digunakan sebagai sumber data spasial adalah mosaik citra foto udara format kecil yang diperoileh dengan menggunakan wahana pesawat udara tanpa awak. Pemotretan dilakukan pada 30 Januari 2016 dengan menggunakan kamera DJI model FC300X, f-stop: $\mathrm{f} / 2.8$, exposure time $1 / 565$ seconds, ISO speed ISO-100, ex posure bias: 0 step, dan focal length $4 \mathrm{~mm}$. Wahana yang digunakan pesawat tanpa awak DJI. Tinggi terbang saat pemotretan 85 meter dari permukaan lahan Hasil pemotretan adalah foto udara format kecil atau sering disebut dengan SFAP (small format aerial photographs) dengan spesifikasi : ukuran setiap citra SFAP 4000 x 3000 piksel, atau 4.000 baris dan 3.000 kolom, dengan resolusi spasial 72 dpi atau sekitar 2,8 $\mathrm{mm}$. Ekstraksi data spasial bangunan gedung di ling kungan kampus UGM dilakukan melalui interpretasi visual mosaik citra SFAP. Survei lapangan bertujuan untuk mendapatkan data fasilitas bagi penyandang disabilitas pada seluruh bangunan gedung yang ada di lingkungan kampus UGM dan fungsi pemanfaatan gedungnya. Teknik survei lapangan dilakukan secara sensus pada seluruh bangunan gedung yang ada di lingkungan kampus UGM. Survei lapa ngan juga difungsikan untuk menambah data spasial bangunan gedung yang baru, yang belum ada saat pemotre tan dengan menggunakan pesawat tanpa awak. Survei lapa ngan dilakukan pada tanggal 20 - 30 Juli 2019. Hasil survei lapangan adalah data tabuler fasilitas bagi penyandang disa bilitas dan fungsi pemanfaatan bangunan gedung di ling kungan kampus UGM. Untuk membatasi wilayah kajian digunakan peta batas wilayah kampus UGM.

Basis data spasial fasilitas bangunan gedung bagi penyan dang disabilitas diperoleh dengan memadukan data spasial dan data atribut. Data spasial berupa bangunan gedung di lingkungan kampus UGM, sedangkan data atribut berasal dari data tabuler keberadaan fasilitas bagi penyandang disabilitas, berupa : ramp atau lift, guiding block, dan fasilitas

Tabel 1. Jenis dan Sumber Data Penelitian

\begin{tabular}{ll}
\hline \multicolumn{1}{c}{ Jenis } & \multicolumn{1}{c}{ Sumber Data } \\
\hline Batas Kampus UGM & Peta UGM \\
Bangunan gedung & Citra penginderaan jauh \\
Pemanfaatan bangunan gedung & Survei lapangan \\
Fasilitas bagi penyandang disabilitas & Survei lapangan \\
Penyandang disabilitas & Survei lapangan dan data sekunder \\
\hline
\end{tabular}

Sumber: Telaah pustaka 


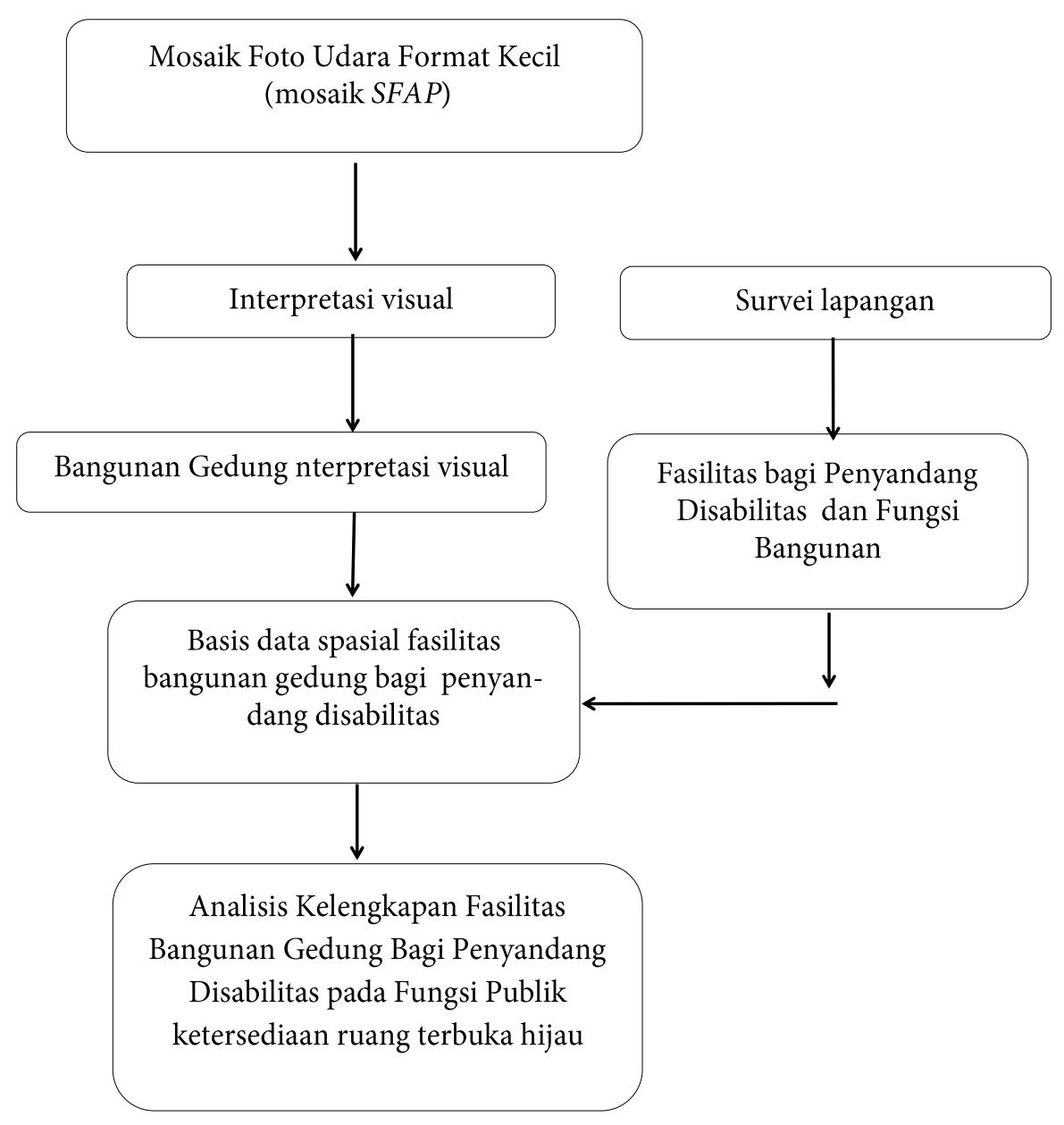

Gambar 1. Diagram Alur Penelitian

toilet. Analisis data dilakukan dengan menghitung kelengkapan fasilitas bagi penyandang disabilitas pada setiap bangunan gedung yang difungsikan untuk dapat diakses oleh publik. Hasil kajian berupa peta kelengkapan fasilitas bagi penyandang disabilitas pada setiap bangunan gedung dan rekomendasi untuk melengkapi fasilitas bagi penyandang disabilitas bagi gedung yang belum lengkap. Secara rinci tahapan penelitian dapat dilihat pada Gambar 1, diagram alir penelitian.

\section{HASIL DAN PEMBAHASAN}

Aksesibilitas menurut Peraturan Menteri Pekerjaan Umum dan Perumahan Rakyat RI No. 14/PRT/M/2017 adalah kemudahan yang disediakan bagi semua guna mewujudkan kesamaan kesempatan dalam segala aspek kehidupan dan penghidupannya. Perancangan dan perencanaan fasilitas yang dapat diakses terkait harus memenuhi prinsip desain universal (universal design) dimana rancangan bangunan gedung dan fasilitasnya dapat digunakan semua orang secara bersama-sama tanpa diper lukan adaptasi atau perlakuan khusus (Wardhani, 2016). Selanjutnya, prinsip desain universal ini meliputi 7 aspek, yaitu (1) kesetaraan penggunaan ruang, (2) keselamatan dan keamanan bagi semua, (3) kemudahan akses tanpa hambat an, (4) kemudahan akses informasi, (5) kemandirian penggunaan ruang, (6) efisiensi upaya pengguna dan (7) ke sesuaian ukuran dan ruang secara ergonomik. Secara khusus, Permen 14/PRT/M/2017 menyebutkan bahwa prinsip desain universal harus mempertimbangkan kebutuhan dan kemam puan penyandang disabilitas, anak-anak, lanjut usia dan ibu hamil. Hal lain yang diatur dalam permen tersebut adalah terkait dengan ukuran dasar ruang, jalur pedestrian, jalur pemandu, area parkir, pintu, ram, tangga, lift, toilet, pancu ran, wastafel, telepon, perlengkapan dan peralatan kontrol, perabot, serta rambu dan marka yang bisa digunakan secara mandiri oleh penyandang disabilitas. Universitas Gadjah Mada sebagai kampus inklusif yang sangat konsen terkait dengan fasilitas bagi penyandang disabilitas. Oleh karena itu, UGM menyediakan berbagai fasilitas yang tersebar dalam semua Gedung UGM diantaranya:

Lift

Untuk bangunan lebih dari 2 lantai, paling tidak disediakan 1 buah lift yang dapat diakses dan terdapat jalur aksesibilitas yang memenuhi standar dan teknis berlaku bagi penyandang disabilitas. Ruang koridor penunggu lift juga disediakan sebagai area untuk melihat sirkulasi keluar masuk orang ke dalam lift. Peletakan tombol dan layar tampilan yang mudah dijangkau oleh disabilitas, panel luar yang berisikan tombol lift dipasang di tengah-tengah dengan ketinggian 90-100 cm dari muka lantai bangunan, dan panel dalam dari tombol lift dipasang dengan ketinggian 90-120 $\mathrm{cm}$ dari muka lantai lift. Ruang lift dapat digunakan bagi pengguna kursi roda, mulai dari masuk melewati pintu lift, dan dilengkapi dengan pegangan rambat (handrail) pada ketiga sisinya.

Toilet

Kamar kecil sudah dilengkapi dengan kamar mandi khusus disabilitas, serta memiliki ruang gerak yang cukup 
untuk keluar masuk bagi pengguna. Kloset disesuaikan dengan ketinggian pengguna kursi roda dan dilengkapi dengan handrail yang memiliki posisi dan ketinggian yang sama dengan pengguna kursi roda. Universitas Gadjah Mada su dah memberikan fasilitas toilet bagi penyandang disabilitas yaitu fasilitas sudah tersedia pada Fakultas Geografi, Fakultas Kedokteran, Fakultas Farmasi, Kehutanan, Teknologi Per tanian, Fakultas Ilmu Budaya, Fakultas Teknik, MM UGM, dan Fakultas Ekonomika dan Bisnis. Secara spasial distribusi persebaran fasilitas disabilitas dapat dilihat pada Gambar 2.
Aksesibilitas untuk Pengguna Kursi Roda

Sesuai dengan Keputusan Menteri Pekerjaan Umum No mor 468/KPTS/1998 tentang Persyaratan Teknis Aksesibili tas pada Bangunan Umum dan Lingkungan, aksesibilitas adalah kemudahan yang disediakan bagi penyandang cacat untuk memberikan kesempatan yang sama dalam berbagai aspek kehidupan. Secara spasial Gedung yang dapat diakses secara penuh pada setiap lantai oleh penyandang disabilitas adalah 2 gedung pada Fakultas Teknik, 3 gedung pada Ma gister Manajemen, 1 gedung pada Fakultas Geografi, 1 gedung pada Fakultas Biologi, 1 gedung pada Fakultas Teknologi Pertanian, 2 gedung pada Fakultas Kedokteran

PETA KETERSEDIAAN FASILITAS TOILET BAGI DISABILITAS

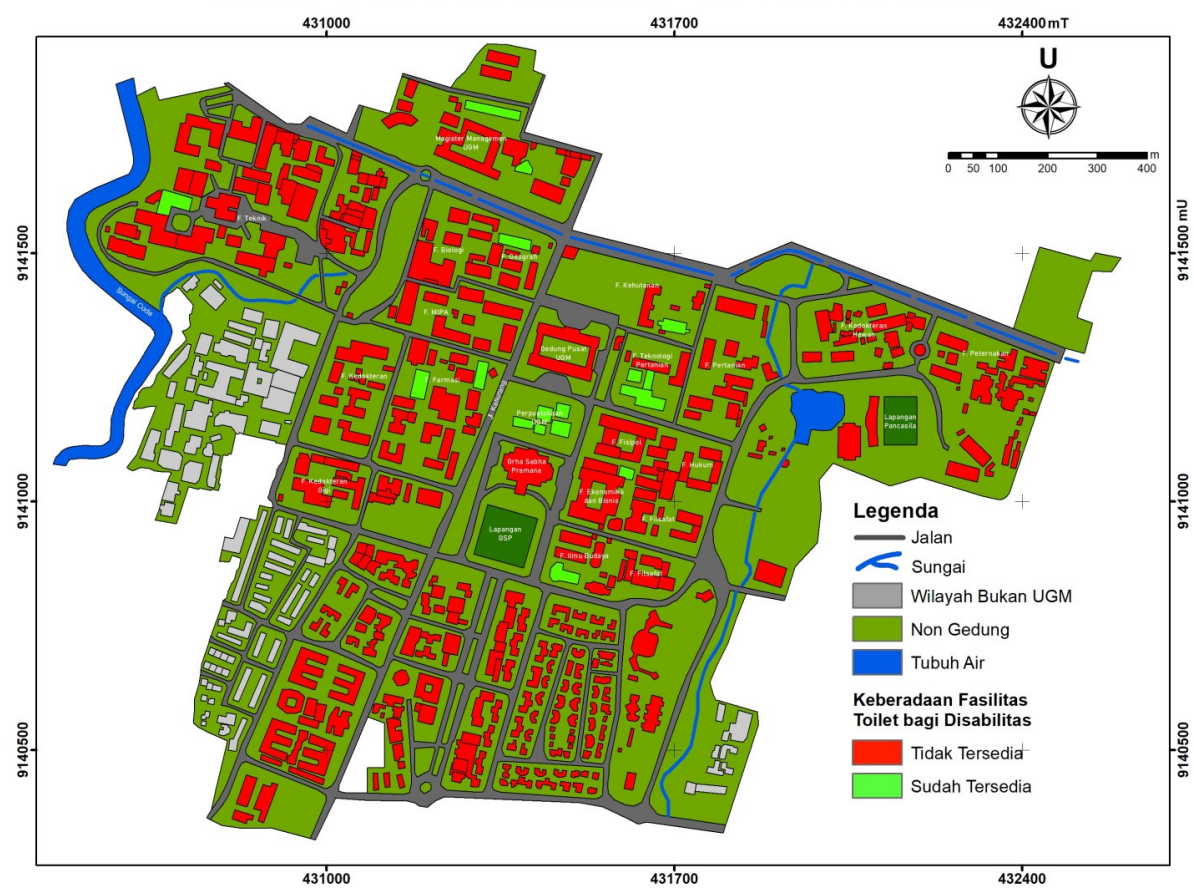

Gambar 2. Peta Ketersediaan Toilet bagi peserta difabel

PETA TINGKAT AKSESBILITAS BAGI DISABILITAS PENGGUNA KURSIRODA

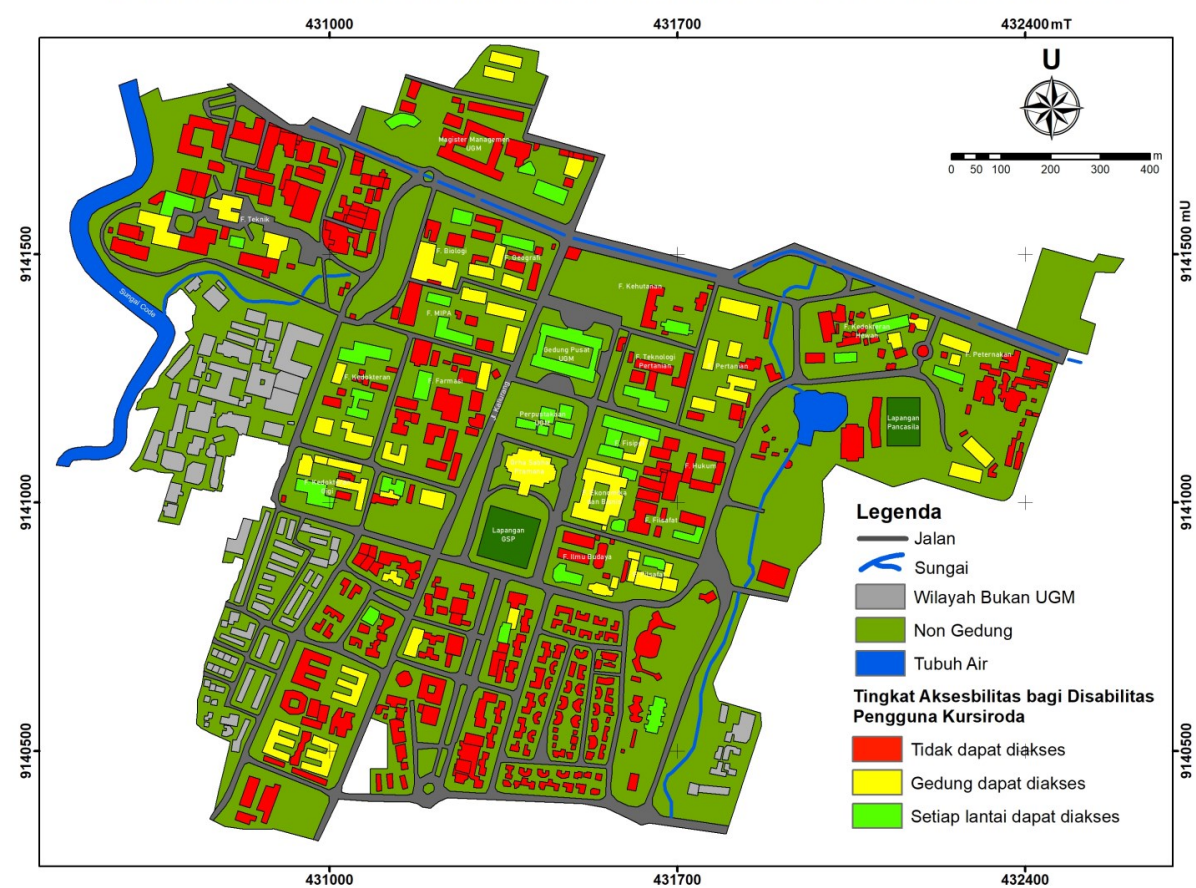

Gambar 3. Peta Aksesibilitas Kursi Roda 
Hewan, 1 gedung pada Fakultas Peternakan, 75\% gedung pada Fakultas Isipol, 1 gedung pada Fakultas Filsafat, 1 gedung pada Fakultas Ilmu Budaya, dan Perpustakaan UGM (Gambar 3).

Sesuai dengan Peraturan Menteri Pekerjaan Umum (Permen PU) Nomor 30 Tahun 2006 tentang pedoman teknis fasilitas dan aksesibilitas pada bangunan dan lingkungan menyatakan bahwa penyandang disabilitas mempu nyai hak sepenuhnya untuk diberi kemudahan akses pada selurug bangunan maupun di lingkungan sekitarnya. Tekstur ubin yang digunakan untuk guiding block bermotih garis-garis yang menunjukkan perjalanan (jalan terus) sedangkan tekstur ubun peringatan (warning block) bermotif bulat-bulat yang artinya bahwa terdapat bahaya di sekitarnya.
Dae rah yang harus menggunakan ubin pemandu (guding blocks) adalah area lalu lintas kendaraan, depan pintu masuk atau keluar dari tangga, fasilitas persilangan dengan perbedaan ketinggian lantai, dan terminal untuk transportasi umum (Sari dkk., 2015). Syarat utama pemasangan ubin ini harus memberikan orientasi yang jelas kepada penggunanya . Ubin ini harus menggunakan material yang kuat, tidak licin, dan diberikan warna yang kontras dengan trotoar di sekitarnya. Apabila dilihat pada Gambar 3, fasilitas bangunan di UGM masih banyak yang belum memiliki guding block, sehingga perlu dibangun fasilitas ini bagi penyandang disabilitas. Ketersediaan fasilitas penyandang disabilitas secara detail tertuang pada Gambar 4.

\section{PETA KETERSEDIAAN FASILITAS GUIDING BLOCK BAGI TUNANETRA}

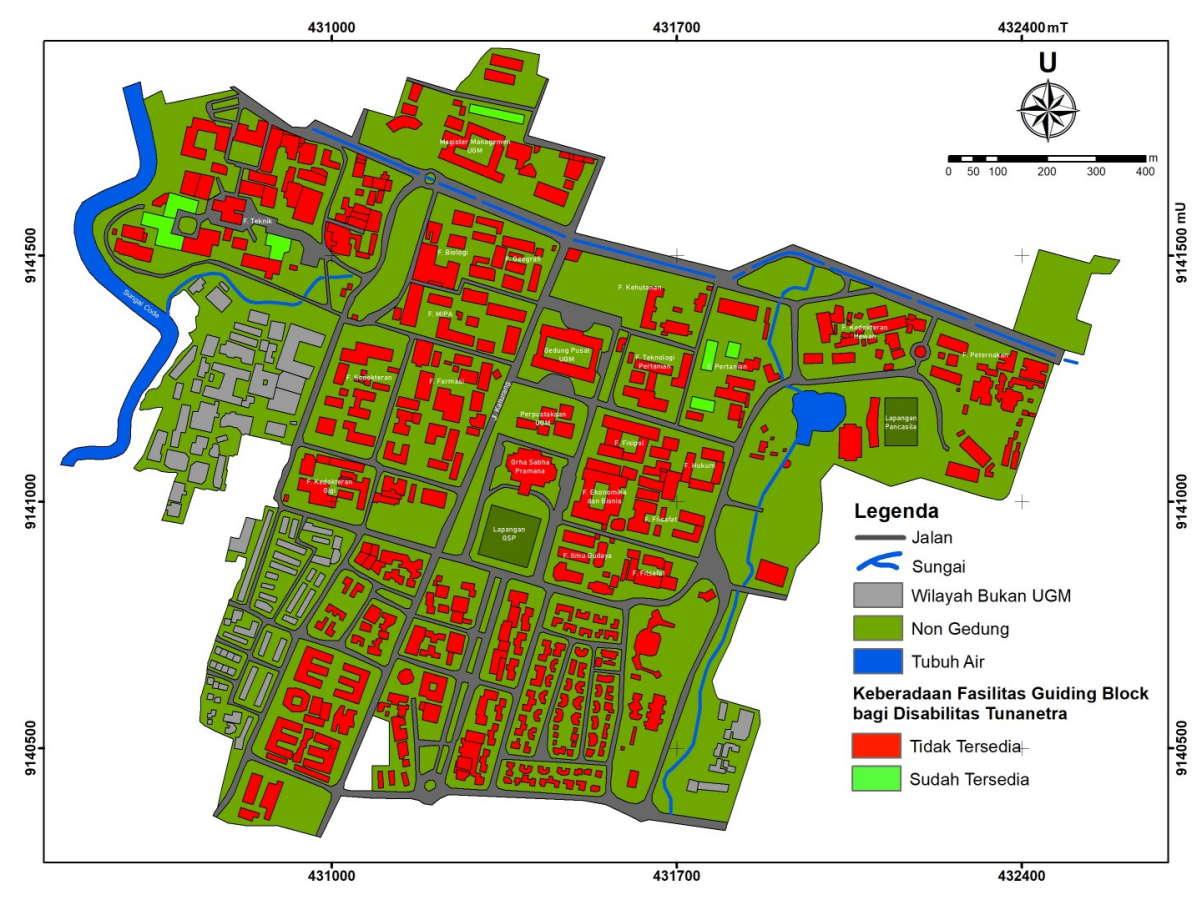

Gambar 3. Peta Ketersediaan Guiding Block bagi tuna netra

PETA KELENGKAPAN FASILITAS PENUNJANG DISABILITAS

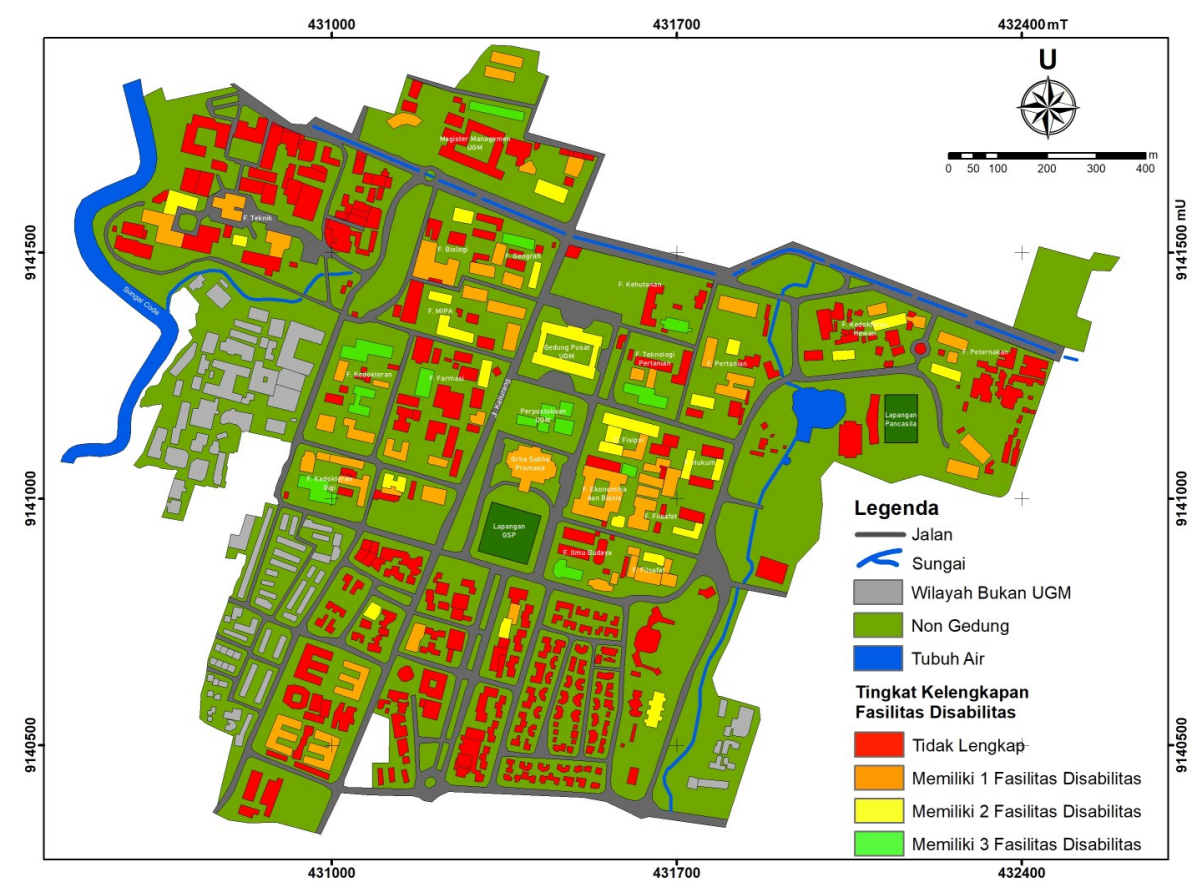

Gambar 3. Peta Kelengkapan Fasilitas Penunjang Disabilitas 


\section{KESIMPULAN}

Adanya fasilitas di gedung dan lingkungan kampus UGM yang dapat diakses merupakan perwujudan komitmen UGM sebagai kampus ramah inklusi. Dari hasil penelitian dapat disimpulkan bahwa jalur pejalan kaki di lingkungan UGM masih perlu ditingkatkan khususnya terkait penyandang dis abilitas. Pintu dan lift juga harus disesuaikan lagi dengan aksesibilitas penyandang disabilitas. Perlu adanya peningkatan dan jumlah toilet untuk penyandang disabilitas.

\section{UCAPAN TERIMA KASIH}

Penulis mengucapkan terima kasih kepada : (1) Fakultas Geografi UGM yang telah menyelenggarakan penelitian hi bah mandiri sehingga penelitian ini dapat berjalan dengan lancar; (2) asisten peneliti, Viky Citrasari Juniandari dan Siddiq Luqman Rifai yang membantu mengolah data.

\section{KONTRIBUSI PENULIS}

Penulis melakukan kajian literatur, pengolahan data, hingga sampai penyajian data penelitian.

\section{DAFTAR PUSTAKA}

Čerešňová, Z. (2018). Inclusive higher education. (J. Langer \& E. Mendelová, Eds.) (1st ed.). Prague: Nakladetelstvi Gasset Allan Gintel. Retrieved from https://www.ap3sp.cz/publicdocuments/inclusive-higher-education.pdf

Haug, P. (2017). Understanding inclusive education: ideals and reality. Scandinavian Journal of Disability Research, 19(3), 206-217. https://doi.org/10.1080/15017419.2016.1224778

Herold, M., Member, S., Gardner, M. E., \& Roberts, D. A. (2003). Spectral Resolution Requirements for Mapping Urban Areas, 41(9), 1907-1919.

Hewett, R., Douglas, G., McLinden, M., \& Keil, S. (2018). Balancing inclusive design, adjustments and personal agency: progressive mutual accommodations and the experiences of university students with vision impairment in the United
Kingdom. International Journal of Inclusive Education, $0(0)$, 1-17. https://doi.org/10.1080/13603116.2018.1492637

Mag, A. G., Sinfield, S., \& Burns, T. (2017). The benefits of inclusive education: New challenges for university teachers. MATEC Web of Conferences, 121, 1-7. https://doi.org/10.1051/ matecconf/201712112011

Morgado, B., Cortés-Vega, M. a. D., López-Gavira, R., Álvarez, E., \& Moriña, A. (2016). Inclusive Education in Higher Education? Journal of Research in Special Educational Needs, 16, 639-642. https://doi.org/10.1111/14713802.12323

Morina, A. (2017). Inclusive education in higher education: challenges and opportunities. European Journal of Special Needs Education, 32(1), 3-17.

Moriña Díez, A., López, R. G., \& Molina, V. M. (2015). Students with disabilities in higher education: a biographical-narrative approach to the role of lecturers. Higher Education Research and Development, 34(1), 147159. https://doi.org/10.1080/07294360.2014.934329

Pemerintah Republik Indonesia. (2016). Undang Undang Republik Indonesia Nomor 8 Tahun 2016, tentang Penyandang Disabilitas.Jakarta : Kemensetneg

Sari, R. O., Dewi, D. I. K., \& Diponegoro, U. (2015). Pemanfaatan Jalur Pemandu Tunanetra Pada Pedestrian Di Kota Semarang. Ruang, 1(1), 11-20. https://doi.org/10.14710/ ruang.1.1.11-20

Suharyadi, R. (2011). Hybrid Interpretation of medium spatial resolution satellite imagery for urban study in building densification area (the case of Yogyakarta urban area. Gadjah Mada University.

Suharyadi, R. (2014). Estimasi kebutuhan ruang parkir dari citra penginderaan jauh di Kota Yogyakarta. Yogyakarta.

Tuggar, A. M. (2014). Benefits of inclusive education to the education of special needs children. National Journal of Inclusive Education, 1(1), 106-109.

Wardhani, F. K. (2016). Kajian Sign sistem bagi tunanetra di sekolah luar biasa, 3(3), 1150-1160.

Yang, X., \& Liu, Z. (2005). Use of satellite-derived landscape imperviousness index to characterize urban spatial growth, 29, 524-540. https://doi.org/10.1016/ j.compenvurbsys.2005.01.005. 